\title{
Purification and partial characterization of Phaseolus vulgaris seed aminopeptidase
}

A.P. Abdala, L.H. Takeda, J.O. Freitas Jr. and K.B. Alves
Departamento de Bioquímica, Escola Paulista de Medicina, Universidade Federal de São Paulo, São Paulo, SP, Brasil

\section{Correspondence \\ K.B. Alves \\ Departamento de Bioquímica EPM, UNIFESP \\ Rua 3 de Maio, 100, 5 andar 04044-020 São Paulo, SP \\ Brasil \\ Fax: + 55-11-572-3006 \\ E-mail: kbisan.bioq@epm.br \\ Presented at the XIV Annual Meeting of the Federação de Sociedades de Biologia Experimental, Caxambu, MG, Brasil, August 25-28, 1999. \\ A.P. Abdala and L.H. Takeda are recipients of fellowships from $\mathrm{CNPq}$ and PIBIC. Publication supported by FAPESP.}

Received March 11, 1999 Accepted October 5, 1999

\section{Abstract}

The aminopeptidase activity of Phaseolus vulgaris seeds was measured using L-Leu-p-nitroanilide and the L-aminoacyl-ß-naphthylamides of Leu, Ala, Arg and Met. A single peak of aminopeptidase activity on Leu-ß-naphthylamide was eluted at $750 \mu \mathrm{S}$ after gradient elution chromatography on DEAE-cellulose of the supernatant of a crude seed extract. The effluent containing enzyme activity was applied to a Superdex 200 column and only one peak of aminopeptidase activity was obtained. SDS-polyacrylamide gel electrophoresis $(10 \%)$ presented only one protein band with molecular mass of $31 \mathrm{kDa}$ under reducing and nonreducing conditions. The aminopeptidase has an optimum $\mathrm{pH}$ of 7.0 for activity on all substrates tested and the highest $\mathrm{Vmax} / \mathrm{K}_{\mathrm{M}}$ ratio for L-Leu- $\beta$-naphthylamide. The enzyme activity was increased $40 \%$ by $0.15 \mathrm{M} \mathrm{NaCl}$, inhibited $94 \%$ by $2.0 \mathrm{mM}$ $\mathrm{Zn}^{2+}$, inhibited $91 \%$ by sodium p-hydroxymercuribenzoate and inhibited $45 \%$ by $0.7 \mathrm{mM}$ o-phenanthroline and $30 \mu \mathrm{M}$ EDTA. Mercaptoethanol (3.3 mM), dithioerythritol (1.7 mM), Ala, Arg, Leu and Met $(70 \mu \mathrm{M})$, p-nitroaniline $(0.25 \mathrm{mM})$ and $\beta$-naphthylamine $(0.53 \mathrm{mM})$ had no effect on enzyme activity when assayed with $0.56 \mathrm{mM}$ of substrate. Bestatin $(20 \mu \mathrm{M})$ inhibited $18 \%$ the enzyme activity. The aminopeptidase activity in the seeds decayed 50\% after two months when stored at $4^{\circ} \mathrm{C}$ and room temperature. The enzyme is leucyl aminopeptidase metal- and thiol group-dependent.
Hydrolysis and mobilization of storage proteins occur during seed germination. Despite the intensive studies on proteolytic activity during seed germination the mechanism of protein degradation is still not well understood. The reserve proteins are broken down by endopeptidases, aminopeptidases and carboxypeptidases yielding amino acids, which are reutilized in the synthesis of new functional proteins. The purification and characterization of these proteases should improve the understanding of the regulation,

\section{Key words}

- Phaseolus vulgaris aminopeptidase

- Bean seed aminopeptidase

- Leucyl aminopeptidase structure and function of these enzymes in seeds.

Aminopeptidases (EC 3.4.11.XX) are enzymes that participate in the final stages of protein degradation and hydrolyze peptide bonds yielding amino acids from $\mathrm{N}$-terminal peptides and proteins and act on some artificial substrates like aminoacyl- $\beta$-naphthylamides (AA-NA) and aminoacyl-p-nitroanilide (AA-Nan). They are found in many subcellular organelles, in the cytoplasm and in the cell membranes (1). Aminopeptidases 
have been purified and characterized from several plant sources such as soybean seeds (2), Enterolobium contortisiliquum seeds (3), barley (4) and mung bean cotyledons (5).

In the present study we describe the purification and characterization of one aminopeptidase from Phaseolus vulgaris seed crude extract which presented arylamidase activity on the L-Leu-p-nitroanilide (LeuNan) and AA-NA of Leu, Ala, Arg and Met. The hydrolysis of AA-NA was measured by the method of Höpsu et al. (6) and that of Leu-Nan by the method of Tuppy at al. (7). Enzyme activity was determined under the following conditions: $0.56 \mathrm{mM}$ substrate, 20 $\mathrm{mM}$ sodium phosphate buffer $(\mathrm{NaPB}), \mathrm{pH}$ 7.0 , at $37^{\circ} \mathrm{C}$ in a final volume of $3 \mathrm{ml}$. One enzyme unit (U) is defined as the amount of enzyme that hydrolyzes $1 \mu \mathrm{mol}$ of substrate per minute at $37^{\circ} \mathrm{C}$ under the conditions of the assay for each particular substrate.

Phaseolus vulgaris seeds (15.47 g) were swollen in water and, after the tegument was removed, homogenized in a blender with 83 $\mathrm{ml} 0.02 \mathrm{M} \mathrm{NaPB}, \mathrm{pH}$ 7.0. The crude extract was filtered and centrifuged at $9000 \mathrm{~g}$ for 30 $\min$ at $4^{\circ} \mathrm{C}$. The supernatant which contained 505 U L-Leu-ß-naphthylamide (LeuNA) activity was submitted to chromatography on DEAE Cellex D, equilibrated and washed with $20 \mathrm{mM}$ NaPB, pH 7.0. Elution with a linear gradient of $20 \mathrm{mM}$ to $200 \mathrm{mM}$ $\mathrm{NaPB}, \mathrm{pH}$ 7.0, provided only one peak with activity on AA-NA of Leu, Arg, Ala and Met as substrate. The effluent containing activity, eluted at $0.7 \mathrm{mS}$, was lyophilized and filtered on a Superdex 200 column, equilibrated and developed with $0.1 \mathrm{M}$ Tris- $\mathrm{HCl}$, $\mathrm{pH} 8.0$, containing $0.15 \mathrm{M} \mathrm{NaCl}$. Only one peak with activity on Leu-NA (112 U) was obtained. Molecular mass estimated by gel filtration was $31 \mathrm{kDa}$. Protein was determined using Coomassie brilliant blue (8). Bovine serum albumin was used as standard.

SDS-polyacrylamide gel electrophoresis, performed on $10 \%$ gel with reduced and nonreduced samples under the conditions described by Laemmli (9) and stained with silver nitrate, showed only one protein band of $31 \mathrm{kDa}$. Phosphorylase b (97.4 kDa), bovine serum albumin $(66.0 \mathrm{kDa})$, ovalbu$\min (43.0 \mathrm{kDa})$, carbonic anhydrase $(29.0$ $\mathrm{kDa})$ and soybean trypsin inhibitor (21.5 $\mathrm{kDa}$ ) were used as standards.

Enzyme activity was stable for about 30 days at $4^{\circ} \mathrm{C}$ in $10 \mathrm{mM}$ sodium phosphate buffer, $\mathrm{pH}$ 7.0. The optimum $\mathrm{pH}$ of activity was 7.0 for Leu-Nan and AA-NA of Leu, Ala, Met and Arg as substrates, using different buffers with $\mathrm{pH}$ varying from 4.0 to 9.5 . The enzyme preparation did not hydrolyze Glu-NA in the presence of $3.3 \mathrm{mM} \mathrm{CaCl} 2$ (10).

Kinetic parameters for the aminopeptidase were determined using Leu-Nan and different AA-NA as substrates (Table 1). Vmax and $K_{M}$ values were estimated by the double-reciprocal Lineweaver-Burk plots of initial velocity data (11). Statistical analysis was performed using the variance of velocity by the method of Wilkinson (12). The highest catalytic efficiency $\left(0.15 \mathrm{nmol} \mathrm{mg}^{-1}\right.$ $\mathrm{s}^{-1} \mu \mathrm{M}^{-1}$ ) was obtained with Leu-NA, showing that the enzyme is similar to aminopeptidases of mung been (5) and soybean cotyledons (13).

To study the effect of aging seeds on the aminopeptidase activity, seeds were kept at room temperature and at $4^{\circ} \mathrm{C}$. The aminopeptidase activity on Leu-NA was determined using a crude extract prepared from seeds of both groups as described before, at different times. After two months the enzyme activity decreased 50\% in both groups.

The effect of different chemicals on the aminopeptidase activity is shown in Table 2. The rate of Leu-NA hydrolysis was increased $40 \%$ by $0.15 \mathrm{M} \mathrm{NaCl}$. Divalent cations such as $\mathrm{Ca}^{2+}$ and $\mathrm{Mg}^{2+}(2.0 \mathrm{mM})$ had no effect on the enzyme activity, while $\mathrm{Mn}^{2+}$ and $\mathrm{Co}^{2+}$ $(0.5 \mathrm{mM})$ activated it by about $25 \%$. The enzyme was strongly inhibited by $0.5 \mathrm{mM}$ $\mathrm{Zn}^{2+}$.

Chelating agents such as ethylenedia- 
Table 1 - Kinetic parameters of Phaseolus vulgaris seed aminopeptidase acting on B-naphthylamides (NA) of several amino acids and on L-Leu-p-nitroanilide (Leu-Nan).

Experiments were performed in $20 \mathrm{mM}$ sodium phosphate buffer, $\mathrm{pH} 7.0$, at $37^{\circ} \mathrm{C}$ with 8.4 to $2.2 \mathrm{mM}$ substrate concentration. Data are reported as means \pm SEM for 5 determinations each on 3 preparations.

\begin{tabular}{|c|c|c|c|}
\hline Substrate & $\mathrm{K}_{\mathrm{M}}(\mu \mathrm{M})$ & $\operatorname{Vmax}\left(\mathrm{nmol} \mathrm{mg}^{-1} \mathrm{~s}^{-1}\right)$ & $\operatorname{Vmax} / K_{M}\left(n m o l ~ g^{-1} s^{-1} \mu M^{-1}\right)$ \\
\hline Leu-NA & $19.2 \pm 0.1$ & $2.78 \pm 0.43$ & 0.15 \\
\hline Arg-NA & $29.8 \pm 0.1$ & $3.29 \pm 0.79$ & 0.11 \\
\hline Met-NA & $89.5 \pm 0.3$ & $4.61 \pm 0.36$ & 0.05 \\
\hline Ala-NA & $164.0 \pm 0.5$ & $3.14 \pm 0.27$ & 0.02 \\
\hline Leu-Nan & $123.1 \pm 0.2$ & $7.25 \pm 0.03$ & 0.06 \\
\hline
\end{tabular}

Table 2 - Effect of various chemicals on the aminopeptidase activity of Phaseolus vulgaris seeds.

Assays were carried out at $37^{\circ} \mathrm{C}$ in $20 \mathrm{mM}$ sodium phosphate buffer, $\mathrm{pH}$ 7.0. The enzyme was pre-incubated with each chemical for $15 \mathrm{~min}$ at $37^{\circ} \mathrm{C}$, before the addition of substrate. Leu-NA, L-Leu-ß-naphthylamide; LeuNan, L-Leu-p-nitroanilide; o-PHE, o-phenanthroline; EDTA, ethylenediaminetetraacetic acid; pOHMB, sodium p-hydroxymercuribenzoate; 2-ME, 2-mercaptoethanol; DTE, dithioerythritol.

\begin{tabular}{lcccc}
\hline & Chemical & Concentration $(\mathrm{mM})$ & Residual activity (\%) & Substrate \\
\hline \multirow{2}{*}{ lons } & $\mathrm{NaCl}$ & 150.0 & 140.0 & Leu-NA \\
& $\mathrm{ZnCl}_{2}$ & 0.5 & 6.0 & Leu-NA \\
& $\mathrm{MgCl}_{2}$ & 0.2 & 100.0 & Leu-NA \\
& $\mathrm{CaCl}_{2}$ & 2.0 & 100.0 & Leu-NA \\
& $\mathrm{MnCl}_{2}$ & 0.5 & 120.0 & Leu-NA \\
& $\mathrm{CoCl}_{2}$ & 0.5 & 125.0 & Leu-NA \\
Chelating agents & o-PHE & 0.7 & 57.0 & Leu-NA \\
& $\mathrm{EDTA}$ & 0.03 & 56.0 & Leu-NA \\
Sulfhydryl group reagents & pOHMB & 0.08 & 9.0 & Leu-Nan \\
& 2-ME & 3.3 & 100.0 & Leu-Nan \\
& DTE & 1.7 & 100.0 & Leu-Nan \\
Antibiotic & Bestatin & 0.02 & 82.0 & Leu-NA \\
L-amino acids & Ala & 0.07 & 100.0 & Ala-NA \\
& Arg & 0.07 & 100.0 & Arg-NA \\
& Leu & 0.07 & 100.0 & Leu-NA \\
& Met & 0.07 & 100.0 & Met-NA \\
Cyclic compounds & p-nitroaniline & 0.25 & 98.0 & Leu-NA \\
& B-naphthylamine & 0.53 & 100.0 & Leu-Nan
\end{tabular}

minetetraacetic acid (EDTA) and o-phenanthroline (o-PHE) inhibited the aminopeptidase activity by about $54 \%$, suggesting that the enzyme is a metal-dependent aminopeptidase.

The enzyme activity was inhibited $91 \%$ by sodium p-hydroxymercuribenzoate (pOHMB), suggesting the presence of an important thiol group in the catalytic center of the enzyme. The enzymes from Vigna radiata (5) and soybean cotyledons (13) also require a free sulfhydryl group for their activity. Phaseolus vulgaris aminopeptidase was not inhibited by -S-S- group reagents as 2-mercaptoethanol (2-ME) and dithioerythritol (DTE). These data agree with the results of SDS-PAGE, with and without dithiothreitol, suggesting the presence of only one pro- 
tein chain in the enzyme.

Bestatin $(0.02 \mathrm{M})$, a known inhibitor of leucyl aminopeptidases (14), only partially inhibited (18\%) Phaseolus vulgaris aminopeptidase.

Since the aromatic product and the amino acids resulting from the reaction between the aminopeptidase and the aromatic substrate may inhibit the enzyme activity, we studied the effect of Leu, Arg, Ala, Met, B-naphthylamine and p-nitroaniline on the activity of the enzyme. Table 2 shows that the amino acids studied, p-nitroaniline and B-naphthylamine, have no regulatory effect on enzyme activity and both substrates (AA-NA and AA-Nan) may be used for the determination of Phaseolus vulgaris seed aminopeptidase activity. Soybean seed aminopeptidase is inhibited by $\mathrm{p}$-nitroaniline $(\mathrm{Ki}=2.71 \mathrm{mM})$ but not by ß-naphthylamine $(6.7 \mathrm{mM})$, while Enterolobium contortisiliquum seed aminopeptidase is inhibited by B-naphthylamine $(\mathrm{Ki}=0.62 \mathrm{mM})$ and not by $3.3 \mathrm{mM} \mathrm{p}$ nitroaniline (15).

A metal- and thiol group-dependent leucyl aminopeptidase with a molecular mass of $31 \mathrm{kDa}$ was purified to homogeneity from Phaseolus vulgaris seed. In contrast to other leucyl aminopeptidases $(3,16)$, it is activated by chloride ions. There are many differences between the aminopeptidase activity purified from Phaseolus vulgaris and that present in Glycine max seeds (2). The best substrate for activity in soybean is Lys-NA with optimum pH 9.6, molecular mass $65 \mathrm{kDa}$. It is not inhibited by $\mathrm{Zn}^{2+}(0.9 \mathrm{mM})$, pOHMB $(50.0 \mu \mathrm{M})$, EDTA $(33.0 \mu \mathrm{M})$, oPHE $(1.0$ $\mathrm{mM})$ and is inhibited $50 \%$ by DTE $(2.3 \mathrm{mM})$.

\section{References}

1. Taylor A (1993). Aminopeptidases: structure and function. FASEB J oumal, 7: 290298.

2. Alves KB \& Noguti MAE (1989). Partial purification and characterization of soybean seed arylamidase activity. Brazilian J ournal of Medical and Biological Research, 22: 1073-1075.

3. Costa RH, Stella RCR \& Alves KB (1991). Purification and partial characterization of Enterolobium contortisiliquum seed arylamidase. Brazilian J ournal of Medical and Biological Research, 24: 337-344.

4. Holwerda BC \& Rogers JC (1992). Purification and characterization of aleurain. $A$ plant thiol protease functionally homologous to mammalian cathepsin $\mathrm{H}$. Plant Physiology, 99: 848-855.

5. Yamaoka Y, Takeuchi M \& Morohashi $Y$ (1994). Purification and partial characterization from mung bean cotyledons. Physiologia Plantarum, 90: 729-733.

6. Höpsu UK, Mäkinen KK \& Glenner GG (1966). Purification of mammalian peptidase selective for $\mathrm{N}$-terminal arginine and lysine residues: aminopeptidase $\mathrm{B}$. Archives of Biochemistry and Biophysics, 114: 557-566.

7. Tuppy HC, Wiesbauer U \& Wintensberger E (1962). Aminosaure-p-nitroanilide als substrate für aminopeptidases und andere proteolytische fermente. Hoppe Seyler's Zeitschrift für Physiologische Chemie, 329: 278-288.

8. Spector T (1978). Refinement on the Coomassie blue method of protein quantification. A single and linear spectrophotometric assay for 0.5 to $50 \mu \mathrm{g}$ of protein. AnaIytical Biochemistry, 86: 144-146.

9. Laemmli UK (1970). Cleavage of structural proteins during the assembly of the head of bacteriophage T4. Nature, 227: 680-685.

10. Gorvel J P, Benajiba A \& Maroux S (1980). Purification and characterization of the rabbit intestinal brush-border aminopeptidase A. Biochimica et Biophysica Acta, 615: 271-274.

11. Lineweaver H \& Burk D (1934). The determination of enzyme dissociation con- stants. J oumal of the American Chemical Society, 56: 658-666.

12. Wilkinson GN (1961). Statistical estimation in enzyme kinetics. Biochemical J ournal, 80: 324-332.

13. Couton J M, Sarath $G \& \&$ Wagner FW (1991). Purification and characterization of soybean cotyledon aminopeptidase. Plant Science, 75: 9-17.

14. Schaller A, Bergey DR \& Ryan CA (1995). Induction of wound response genes in tomato leaves by bestatin, an inhibitor of aminopeptidases. Plant Cell, 7: 18931898.

15. Alves KB, Costa RH, Aguilar MAG \& Freitas J r J O (1992). Inhibition of aminopeptidase activity by aromatic and other cyclic compounds. Brazilian J ournal of Medical and Biological Research, 25: 1103-1106.

16. Taylor A, Peltier CZ, Torre FJ \& Hakamian N (1993). Inhibition of bovine lens leucine aminopeptidase by bestatin: number of binding sites and slow binding of this inhibitor. Biochemistry, 32: 784-790. 